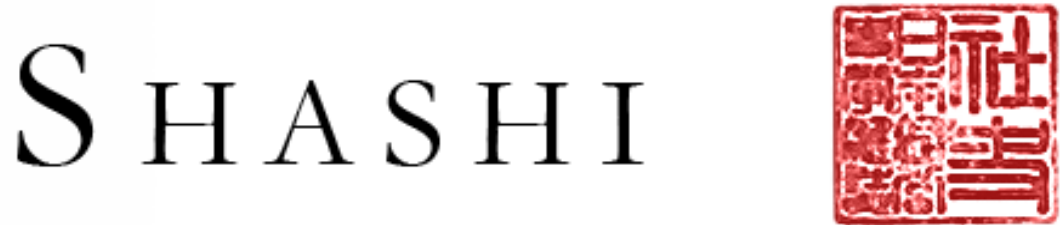

The Journal of Japanese Business and Company History

\section{Centering Shashi and Business Archives as Resources for the Study of Economic and Social History: The Activities of the Shibusawa Eiichi Memorial Foundation}

\author{
Izumi Koide \\ Resource Center for the History of Entrepreneurship \\ Shibusawa Eiichi Memorial Foundation
}

\section{The Resource Center for the History of Entrepreneurship}

\section{Shibusawa Eiichi}

Shibusawa Eiichi (1840-1931) was the first banker in Japan, created the first kabushiki kaisha (stock

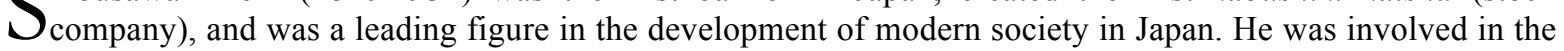
founding of some 500 enterprises and economic organizations, such as the Chamber of Commerce, Bankers Association, and others. He was also active in some 600 social welfare and educational organizations, particularly those for women. Besides his accomplishments in the fields of economy and philanthropy, he devoted himself to international exchange and received many distinguished guests at his residence, including the 18th President of the United States, Ulysses Grant; Chinese leader Chiang Kai-Shek; and Indian poet Rabindranath Tagore.

The Shibusawa Eiichi Memorial Foundation is devoted to honoring and promoting the achievements and high ideals of Shibusawa Eiichi, as well as to raising ethical standards in business based on the ideal of the "harmony of morality and the economy," advocated and practiced by Shibusawa Eiichi throughout his life.

\section{Shibusawa Keizo and his Vision for a "Museum of Japanese Business History"}

In 1937, after the death of Shibusawa Eiichi, his grandson and heir, Shibusawa Keizo, developed a proposal for a museum of Japanese business history. The Nihon Jitsugyoshi Hakubutsukan (Museum of Japanese Business History) would commemorate Shibusawa Eiichi and his achievements. In a statement entitled "A Proposal," Keizo described his idea for a museum commemorating his grandfather that would foster better understanding of his activities while at the same time putting him in historical context and looking at his contemporaries as well. Keizo's proposal was accepted by the Ryumonsha, the predecessor of the Shibusawa Foundation, and acquisitions for the museum collection began. Although the construction of a museum building was set to start in 1939, it had to be postponed because of the war. Then, when the war ended, although the collection remained intact, there was nowhere to house it. As Minister of Finance, Shibusawa Keizo ordered the dissolution of the zaibatsu and, following his own orders, quickly processed his properties. Losing its patron, the jitsugyoshi collection was entrusted, and later donated, to what is now the National Institute of Japanese Literature (Kokubungaku Kenkyu Shiryokan). 
Besides heading the Bank of Japan and Ministry of Finance, and holding leading positions in various banks and businesses, Shibusawa Keizo was also the father of ethnology in Japan and built or helped to build several ethnological collections, one of which formed the core of what became the National Museum of Ethnology (Minpaku) in Osaka. Not only a student of folklore and anthropology himself, Keizo also served as a patron of research and built networks of researchers. He built collections for research, applied classifications to these collections, and made indexes; thus creating information resources for research.

When I was offered the position of director of what was to be a research center on jitsugyoshi, I decided to follow in Keizo's footsteps. As a result, the Center became not simply an ordinary research center but the Resource Center for the History of Entrepreneurship, an institution that aims to create information resources for research on the history of Japanese business and place Eiichi into the context of the modern history of Japan.

Shibusawa Keizo's A Proposal became a guideline for the Center in defining the meaning and scope of "business history." That is to say, the Center used the proposal's descriptions of the industrial fields to be included in the Hall of Modern Economic History and the range of activities of the individuals to be included in the Portrait Gallery to shape the definition and scope of "business history" to be covered by the Center. Despite having a clear definition, however, the area to be covered was still vast and the Center wanted to find a group of materials that could provide a basis and starting point for their activities. Chosen for this purpose were shashi, published volumes of company history, a resource characteristic of the history of Japanese industry.

\section{Shashi: Fundamental Resources for Business History}

The development of information resources was seen to be the technical pillar of the Resource Center for the History of Entrepreneurship, which aspires to be a new cultural institute of the future. However, as discussed above, though this seems new, it is an application of a method proposed by Shibusawa Keizo nearly eighty years ago. By adopting shashi as the mainstay of something equivalent to Keizo's Hall of Modern Economic History, it was believed that the Center's activities in this area could be carried out effectively.

Shashi are published by companies using in-house materials so, although they contain an abundance of information not available elsewhere, they are not released commercially and are not fully utilized by the public. Different from macroeconomic studies, shashi include people's activities, efforts, and lives, as well as economic data, and rich and unique information on the company. Shashi also provide stories of and observations on the inner workings of the company. Often provided chronologically, information in shashi varies from human experiences to business conditions, and may include descriptions of the relationships between the company and the public, not only consumers of the company's products, but society in a wider sense.

Shashi is characterized by in-house publication. The target audience is usually employees and others related to the company. Editorial responsibility often rests with an editorial board within the company and the publisher is almost always the company itself. Therefore, shashi are edited by non-specialized editors and published by nonprofessional publishers. As a result, a large problem often arises: bibliographic information provided in shashi is often inconsistent. Furthermore, there are often discrepancies in the title and the contents or scope of a shashi. For example, a volume entitled "a hundred and twenty year history" may only cover the last 20 years, if a hundred-year history had already been published. It is hard to tell by the title if a volume is a full history or a supplementary volume to previously published shashi. Shashi are grey literature, meaning they are less-known publications that are hard to locate given their limited, private channels of distribution. All of these factors make shashi a nuisance for librarians and researchers, however rich and useful their contents may be.

\section{Company History Index Database}

In 2003, during preparations for the establishment of the Center, ideas on how to utilize shashi were exchanged with Murahashi Katsuko, an expert on company history, then with the Nippon Keidanren Reference Library. The Center's goal was clarified: a database of company history indexes would be built so as to enable shashi to be used as an information resource. At the time, Ms. Murahashi estimated that about 13,000 company histories had been published in total since the Meiji period, but as collections at the Shibusawa Foundation were sorted, it became clear the Foundation had no idea how many volumes it owned. A rough estimate was made of about 1,000 volumes. It was clear that a greater number of shashi would be needed in order to create a database that would be meaningful for research on the history of Japanese industry. 
The decision was made to supplement the shortage in the Foundation's collections and a policy was set to build a larger collection of shashi. The Center actively participated in various external meetings related to shashi and publicized their interest in shashi. As shown in Table 1 (Additions to the Shashi Collection Since 2004), the number of shashi in the Foundation's collection has grown steadily.

Table 1: Additions to the Shashi Collection Since 2004

\begin{tabular}{|l|l|l|l|}
\hline Fiscal Year & $\begin{array}{l}\text { Total No. of } \\
\text { Vols. }\end{array}$ & $\begin{array}{l}\text { No. of Vols. } \\
\text { Purchased }\end{array}$ & $\begin{array}{l}\text { No. of Vols. } \\
\text { Received } \\
\text { Gifts }\end{array}$ \\
\hline 2004 & 739 & & 739 \\
\hline 2005 & 285 & 7 & 278 \\
\hline 2006 & 296 & 4 & 292 \\
\hline 2007 & 120 & 23 & 97 \\
\hline 2008 & 368 & 20 & 348 \\
\hline 2009 & 119 & 24 & 95 \\
\hline 2010 & 104 & 56 & 48 \\
\hline 2011 & 133 & 64 & 69 \\
\hline Total & 2,164 & 198 & 1,966 \\
\hline
\end{tabular}

These numbers include duplicates, however, which were donated elsewhere.

A committee was organized to gather advice from experts for the Company History Index Database. In view of the enormous amount of work to be done, it was necessary to reduce the informational load of the data entry process as much as possible. Four headings were therefore chosen to be input in addition to the bibliographic information: the table of contents, indexes, chronological tables, and materials.

The number of company histories processed and entered into the database by the end of fiscal 2011 is as shown in Table 2. A total of more than 1.8 million entries from over 1,100 volumes of company history were included by this date.

Table 2: Number of Shashi Processed and Data Input

\begin{tabular}{|l|l|l|l|l|l|l|}
\hline \multirow{2}{*}{$\begin{array}{l}\text { Fiscal } \\
\text { Year }\end{array}$} & $\begin{array}{l}\text { Processed } \\
\text { Shashi }\end{array}$ & \multicolumn{4}{l|l}{ Total } \\
\cline { 2 - 7 } & Titles & Vols. & Companies & Titles & Vols. & Entries \\
\hline 2005 & 92 & 125 & 60 & 92 & 125 & 216,447 \\
\hline 2006 & 140 & 160 & 136 & 232 & 285 & 516,482 \\
\hline 2007 & 43 & 53 & 163 & 275 & 338 & 584,312 \\
\hline 2008 & 270 & 283 & 335 & 545 & 621 & $1,102,588$ \\
\hline 2009 & 163 & 199 & 449 & 708 & 820 & $1,405,127$ \\
\hline 2010 & 225 & 259 & 608 & 933 & 1079 & $1,696,409$ \\
\hline 2011 & 134 & 143 & 664 & 1,067 & 1,122 & $1,863,670$ \\
\hline
\end{tabular}

It is yet unclear what type of database structure would best hold the vast amount of data and it will be a big challenge to build a structure with a suitable format. The nature of data varies according to the type of entries inputted, namely the table of contents, indexes, chronological tables, and materials. Tables of contents and indexes may be more useful when linked to bibliographic information in a shashi, while the chronological tables may be 
used more independently from the shashi. An initial consultation regarding ideas and hopes for a possible database structure was held with the National Institute of Informatics in 2012.

The road to a refined shashi database seems long, but since the data is in Microsoft Excel, word matching, counting, arranging and a few other functions are possible. Although the Center is still looking to create a more sophisticated database, the current dataset can still be used for research. Kadokura Yuriko's paper in this issue is an example of one of the uses of the accumulated data.

\section{Shashi Shokai}

Since basic information on shashi was not easily available, the Center created "Shashi Shokai," brief online introductions of shashi in the Foundation's collection. Bibliographic information for various volumes of shashi from the same company, such as a 10-year history and a 30-year history, have been put together under the company's name. As shown in Figure 1, this is a simple list of annotations, arranged by company name in Japanese alphabetical order, and not a database with a search function. The Shashi Shokai Website is: http://www.shibusawa.or.jp/center/shashi/shashi01.html

\begin{tabular}{|c|c|c|c|}
\hline \multicolumn{2}{|l|}{ 掹史紹介 } & \multicolumn{2}{|r|}{ 社史プロジェクト } \\
\hline \multicolumn{4}{|c|}{ 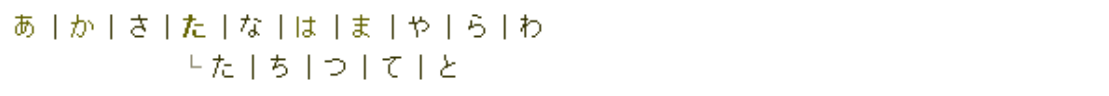 } \\
\hline 会社名(被伝者) & 社史名 & 出版年 & 会社情報\&社史メモ \\
\hline \multirow[t]{3}{*}{ (株)第一勧業銀行 } & $\begin{array}{l}\text { 第一勧業銀行 } 10 \text { 年 } \\
\text { の荹み }\end{array}$ & 1982 & 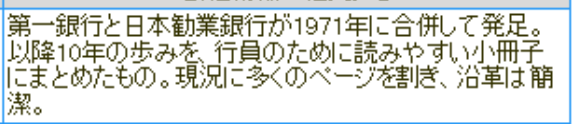 \\
\hline & 二十年のあゆみ & 1991 & 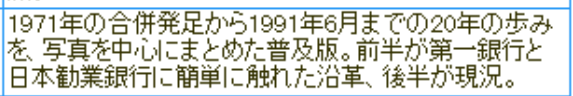 \\
\hline & $\begin{array}{l}\text { 第一勧業銀行二十 } \\
\text { 年史 }\end{array}$ & 1992 & 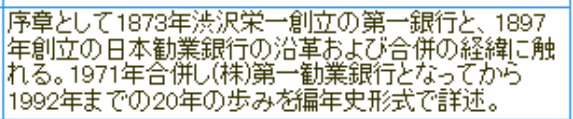 \\
\hline $\begin{array}{l}\text { 株)箅一勧業銀行 } \\
\text { 青采支店 }\end{array}$ & $\begin{array}{l}\text { 第一勧銀青森支店 } \\
\text { 监串 }\end{array}$ & 1986 & 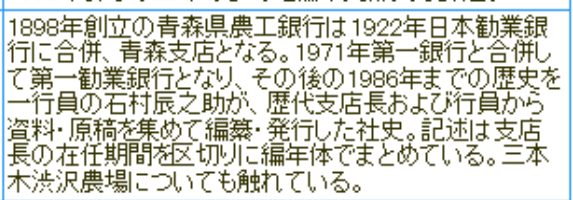 \\
\hline \multirow[t]{5}{*}{ (株)第一銀行 } & 第一銀行五十年小 & 1926 & 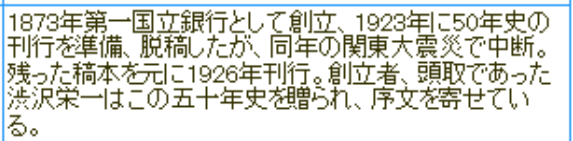 \\
\hline & 第一銀行年表 & 1942 & 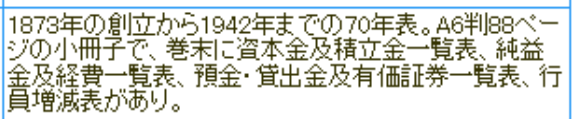 \\
\hline & 第一銀行史 & 1957 & 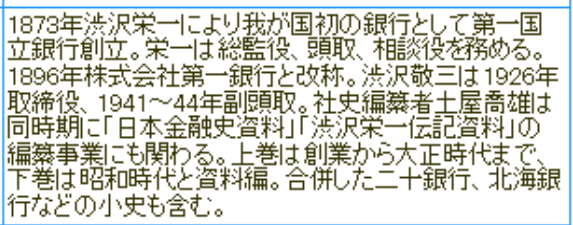 \\
\hline & $\begin{array}{l}\text { 第一銀行小史:九十 } \\
\text { 八年の齿み. }\end{array}$ & 1973 & 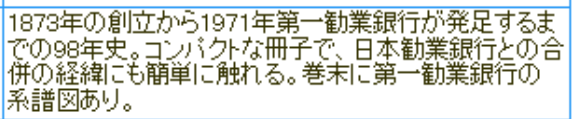 \\
\hline & 第一銀行史追録(艄 & 1977 & 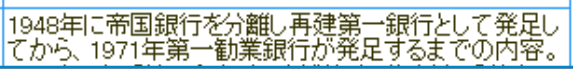 \\
\hline
\end{tabular}

Figure 1: Example of a Shashi Shokai Webpage (for companies beginning with "ta-") 
Contents were first uploaded to the website in the spring of 2006, with annotations for 62 shashi in 93 volumes covering 51 companies. The list has been updated regularly since then and, as of the end of fiscal 2011, contained annotations for 573 shashi in 688 volumes covering 437 companies. See Table 3: Shashi Annotations Published on the Web.

Table 3: Shashi Annotations (Shashi Shokai) Published on the Web

\begin{tabular}{|r|l|l|r|l|r|}
\hline \multirow{2}{*}{ Fiscal Year } & \multicolumn{2}{|l|}{ Annual Additions } & \multicolumn{2}{l|}{ Cumulative Totals } \\
\cline { 2 - 6 } & Titles & Vols. & Companies & Titles & Vols. \\
\hline 2005 & 62 & 93 & 51 & 62 & 93 \\
\hline 2006 & 154 & 176 & 126 & 216 & 269 \\
\hline 2007 & 59 & 70 & 163 & 275 & 338 \\
\hline 2008 & 42 & 42 & 198 & 317 & 381 \\
\hline 2009 & 104 & 113 & 291 & 421 & 494 \\
\hline 2010 & 136 & 168 & 422 & 557 & 662 \\
\hline 2011 & 16 & 25 & 437 & 573 & 688 \\
\hline
\end{tabular}

Annotations can be utilized more broadly when they are combined with bibliographic information. A future development to increase the usability of the annotations might be to include links to the Shashi Wiki, for example.

\section{Name Change Charts of Companies Related to Shibusawa Eiichi}

As preparation for the Company History Index Database was progressing, a discussion developed on whether companies affiliated with Shibusawa should be targeted instead of allowing the scope of the database to expand infinitely. Since no study had been conducted to determine companies affiliated with Eiichi, however, it was unclear which companies had such an affiliation. The Shibusawa Eiichi denki shiryo (Shibusawa Eiichi Biographical Materials) ${ }^{1}$ provided a rough idea with the companies it mentioned, but complicated histories needed to be traced in order to clarify the fate of these companies and under what name they are conducting business today. Though several company history charts had been published for general companies, no information resource was available specifically for companies affiliated with Shibusawa Eiichi.

${ }^{1}$ The Shibusawa Eiichi denki shiryō (Shibusawa Eiichi Biographical Materials) is a collection of primary sources including diary entries, letters, newspaper and journal articles, company reports and other contemporary documents and materials relating to the life and activities of Shibusawa Eiichi.

The Denki shiryō was published in 68 volumes from 1955 to 1971 . The first 57 volumes are arranged by topic in

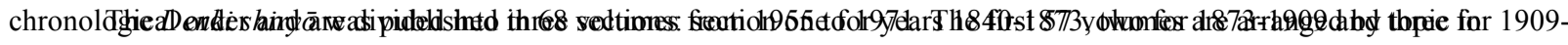
chronological order and are divided into three sections: section one for years 1840-1873, two for 1873-1909 and three for 19091931. Volume 58 contains a chronological index sorted by various activities, a list of items in the previous volumes, and indexes. The last ten volumes include diaries, letters, talks, lectures, calligraphy, and photographs. 
Companies repeatedly undergo mergers, acquisitions, and reorganizations. These types of changes can be extremely complicating but since a company can only be researched if its name is known, the name is the most essential piece of information to identify a company. Thus, understanding name changes is critical to tracing the fate of a company.

Figure 2: Example of a Company Name

Change Chart (a Paper Company)

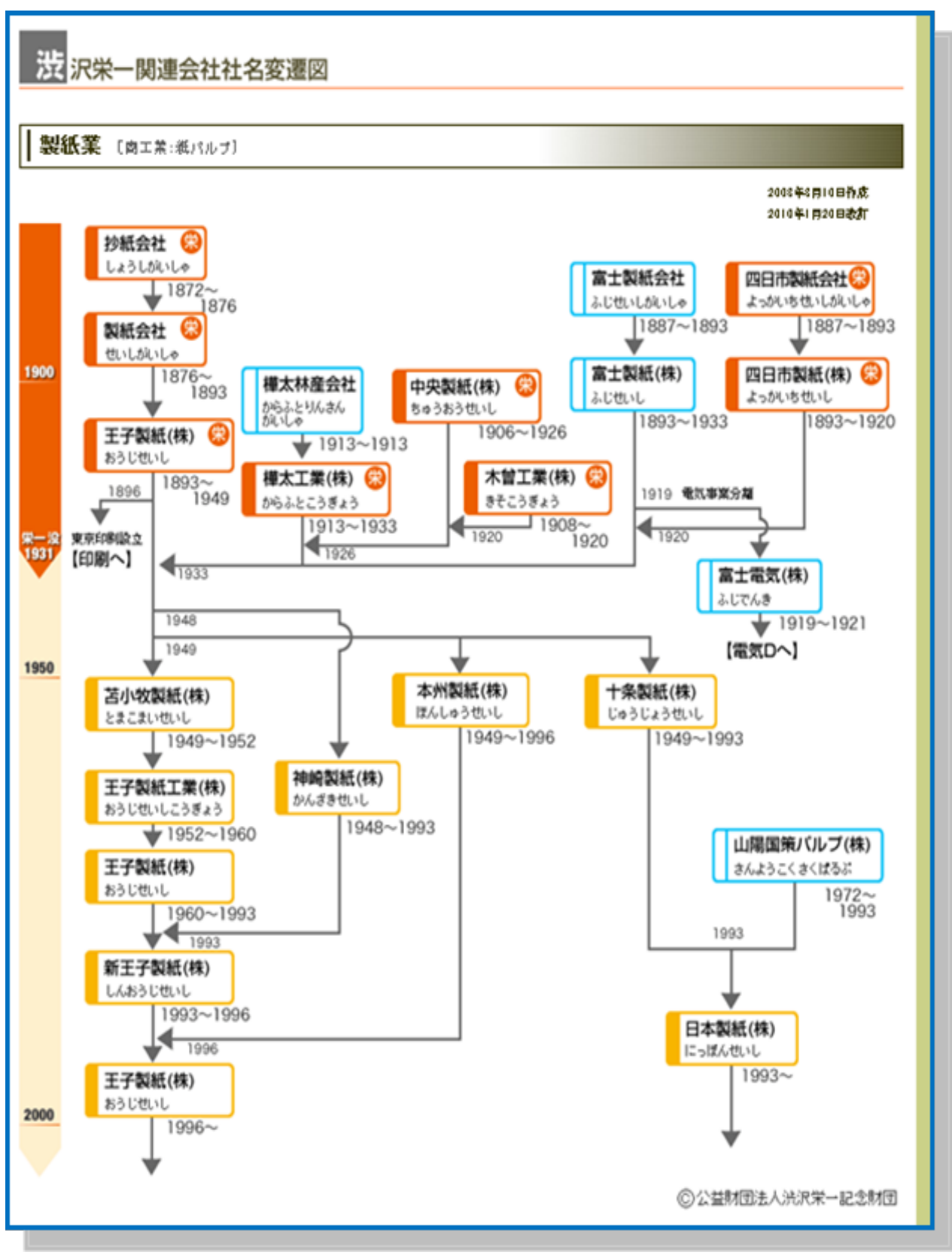

It

concluded that a chart would clearly show the changes better than a table or other form. Using numerous sources, including published shashi, the name changes of companies mentioned in the general index of vol. 58 of the Shibusawa Eiichi denki shiryō were researched. Charts for each industry have been 
drawn into a sort of genealogical map. The companies are divided into three color-coded patterns: companies directly affiliated with Eiichi (in orange), companies with direct affiliation that had subsequently undergone a name change due to merger, acquisition, etc. (in yellow), and other non-affiliated companies (in light blue). The years each company name was used have been added to each name. Figure 2 is an example of a company name change chart. All charts are available at: http://www.shibusawa.or.jp/eiichi/companyname/index.html

The first nine "Name Change Charts of Companies Related to Shibusawa Eiichi" were made available on the website on March 10, 2008. Thereafter more charts were gradually made available as they were drawn and, when the project was completed in 2011 , there were a total of 122 charts covering all the companies and economic organizations related to Shibusawa Eiichi.

Source information was also posted on the web beginning on June 30, 2008. A page was created for each company, listing source materials and explaining Eiichi's relationship with the company (for example, member of the board of directors, shareholder, advisor, or supporter). Since they now provide full citations and leads for detailed research, the usefulness of the charts as reference tools has been increased.

Through the name change charts, the fates of companies mentioned in the Denki shiryo have finally become apparent and Eiichi's relevancy to modern companies has been demonstrated. These charts will help the Center decide whether or not to include a particular company in the shashi database. Table 3 lists the number of charts by industry and the number of companies in the charts, divided by degree of closeness to Eiichi.

Table 3: Number of Charts and Companies in Charts

\begin{tabular}{|l|l|l|l|l|l|}
\hline Type of Industry & $\begin{array}{l}\text { No. of } \\
\text { Charts }\end{array}$ & $\begin{array}{l}\text { Companies } \\
\text { with a Direct } \\
\text { Relationship }\end{array}$ & $\begin{array}{l}\text { Subsequent } \\
\text { Companies }\end{array}$ & $\begin{array}{l}\text { Other } \\
\text { Companies }\end{array}$ & $\begin{array}{l}\text { Total No.of } \\
\text { Companies }\end{array}$ \\
\hline Banks & 20 & 58 & 60 & 143 & 261 \\
\hline Insurance & 10 & 28 & 32 & 89 & 149 \\
\hline $\begin{array}{l}\text { Marine } \\
\text { Transportation }\end{array}$ & 3 & 13 & 4 & 24 & 41 \\
\hline Land Transportation & 11 & 63 & 11 & 54 & 128 \\
\hline Aviation & 1 & 2 & 1 & 1 & 4 \\
\hline Telecommunications & 1 & 3 & 1 & 8 & 12 \\
\hline Textiles & 9 & 30 & 26 & 37 & 93 \\
\hline Paper, Pulp & 1 & 8 & 9 & 5 & 22 \\
\hline Leather & 1 & 7 & 5 & 12 & 24 \\
\hline Foodstuffs & 3 & 11 & 14 & 18 & 43 \\
\hline Ceramics & 4 & 24 & 8 & 14 & 46 \\
\hline Iron and Steel & 3 & 11 & 9 & 19 & 39 \\
\hline Freight Machinery & 4 & 16 & 14 & 19 & 49 \\
\hline Chemicals & 7 & 18 & 11 & 43 & 72 \\
\hline Gas & 2 & 8 & 4 & 14 & 26 \\
\hline Electricity & 4 & 14 & 12 & 46 & 72 \\
\hline Construction & 3 & 17 & 10 & 16 & 43 \\
\hline $\begin{array}{l}\text { Stock, Commodity } \\
\text { and Grain Exchanges }\end{array}$ & 3 & 17 & 6 & 20 & 43 \\
\hline Warehouses & 1 & 8 & 1 & 2 & 11 \\
\hline Hotels & 1 & 6 & 3 & 3 & 12 \\
\hline Foreign Trade & 2 & 10 & 4 & 9 & 23 \\
\hline Printing & 1 & 2 & 4 & 1 & 7 \\
\hline Manufacturing & 2 & 15 & 1 & 12 & 28 \\
\hline & & & & & \\
\hline
\end{tabular}




\begin{tabular}{|c|c|c|c|c|c|}
\hline Service Industry & 2 & 14 & 2 & 12 & 28 \\
\hline $\begin{array}{l}\text { Mining and } \\
\text { Extraction }\end{array}$ & 6 & 16 & 14 & 36 & 66 \\
\hline $\begin{array}{l}\text { Agriculture, Forestry } \\
\text { and Fisheries }\end{array}$ & 4 & 28 & 2 & 14 & 44 \\
\hline Foreign Projects & 7 & 43 & 7 & 14 & 64 \\
\hline $\begin{array}{l}\text { Economic } \\
\text { Organizations }\end{array}$ & 5 & 28 & 5 & 33 & 66 \\
\hline Magazines & 1 & 3 & 4 & 1 & 8 \\
\hline Total & 122 & 521 & 284 & 719 & 1,524 \\
\hline
\end{tabular}

\section{Promoting Business Archives}

The primary mission of the Shibusawa Eiichi Memorial Foundation is to raise the ethical standards of economic activity based on the ideal of the "harmony of morality and the economy," which Shibusawa Eiichi advocated and practiced throughout his life. Since business archives are a record of business operations and provide evidence for tracking a company's activities - thus both illustrating the company's history and ensuring corporate transparency-business records can offer a concrete means for realizing Eiichi's ideal. This realization caused the Center to add raising awareness of the importance of business archives to the scope of its activities.

In-house records, corporate documents, and other items such as advertisements and commodity samples are the main source materials for preparing shashi. These materials provide a basis for research on the company history and its business, upon which the compilation of shashi is then based. While published shashi are certainly source materials for research in business history, particularly by researchers outside the company, and thus valued both inside and outside the company, the corporate records and materials (business archives) that are the sources of shashi do not always receive similar recognition. Although they should be given the highest recognition in regard to learning about the company's activities, in Japan, the value of business records and archives is not widely understood even within companies themselves.

Publishing a shashi provides a company with the opportunity to review their historical documents and records. The shashi editorial office, however, is often a temporary section rather than a standing one. After the shashi is published, most editorial offices are dissolved and no other section in the company is tasked with caring for the organization's documents and records. A famous, but not uncommon, example is the major ship building company that dumped historical documents after it had published a shashi. On the other hand, however, the compilation of a shashi may cause some companies to recognize the importance of historical documents and to create an archival section for keeping these records and documents. In a few cases it has even led to the opening of company history museums.

\section{Business Archives Directory}

Not many companies keep records and documents of their activities indefinitely. Even when they are kept, records tend to be seen as for the exclusive use of the company. To raise awareness on business archives in Japan, the Center's first project was to start a Japanese version of the type of business archives directory that already exists in many countries in the West.

A survey was begun on the location and scale of collections of primary materials for company history. A questionnaire was formulated based on the results of visits to corporations with archives and of discussions with university professors in archival sciences. The questionnaire was sent out with the Business Archives Association newsletter in 2005. A total of 27 valid responses were received. After obtaining confirmation from the responding institutions, information from the first round of responses was organized in a directory format. In March 2007, a trial 
version of the Business Archives Directory was uploaded to the Web. The trial version was only available to those institutions who had answered the survey, because replicate companies were worried about sharing sensitive information.

Later in 2007, while updating the information of the trial version, the companies, organizations, and institutions that had provided information (33 in total) were asked for their participation in making the website available to the general public. Some negative responses were received; however, out of 33 respondent organizations 30 consented to disclosing detailed information. The website was made available to the general public in July 2008 , and has been updated as needed since then. The Business Archives Directory is available at the following URL:.http://www.shibusawa.or.jp/center/dir/list.html

Besides the Business Archives Directory, a new website was created in 2005 to provide information on and raise awareness of business archives. This was substantially renovated in 2006, at which time an English page explaining the Business Archives Directory was added to:http://.shibusawa.or.jp/english/center/shashi/shashi02.html

\section{Conclusion}

Although shashi contain abundant information available publically nowhere else, they have long been grey literature, hard to access physically as well as intellectually. The Resource Center's shashi index database project aims to enable a broader use of shashi as resource for research in economic and industrial history as well as the history of consumer trends, everyday life, fashion, and social change. Although a sophisticated database is still in the process of being built, the amount of data accumulated has reached the point that it can be searched and used for research. The Center is continuing to explore ways in which to make this database and other information, such as annotations of shashi, public and some measures are expected to be made available in the coming years.

While efforts to create the Shashi Index Database continue, a spin-off project, the Name Change Charts Related to Shibusawa Eiichi, has been completed. Focused on companies related to Shibusawa, the name change charts clarify the relevance of Shibusawa to companies in Japan today. Although limited in scope, it is still a convenient tool for research in modern Japanese history as Shibusawa Eiichi was involved in many hundreds of companies.

Records and documents should be archived by companies so that they can compile company histories. It is often the case, however, that archival materials are thrown away after the publication of a shashi despite the fact that academic or public institutions such as university libraries and regional archives might accept discarded archival materials from companies. Thus company or business archives can be housed outside of the company. The compilation of a Business Archives Directory was thought to provide a useful tool for researchers as it offers ideas for tracing source materials for academic research.

By advocating for business archives, the Center's conception of the value of business archives has expanded from a viewpoint focused on outside researchers to one that also looks inside the corporation. The Resource Center's activities now include efforts to spur business archivists and company managers to activate their archives so that they may be tightly integrated into the company's regular operations. This is particularly important because no business archives can survive without an awareness of its importance to the company and, as a result, no accurate shashi would be published. 
New articles in this journal are licensed under a Creative Commons Attribution 3.0 United States License.

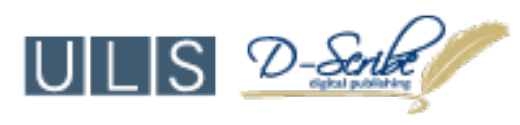

This journal is published by the University Library System, University of Pittsburgh as part of its D-Scribe Digital Publishing Program and is cosponsored by the University of Pittsburgh Press. 